\title{
"Relationship between value added capital employed, value added human capital, structural capital value added and financial performance"
}

\begin{tabular}{|c|c|}
\hline \multirow{3}{*}{ AUTHORS } & Helin Garlinia Yudawisastra (D https://orcid.org/0000-0002-4126-8025 \\
\hline & Daniel T. H. Manurung iD https://orcid.org/0000-0002-8910-1806 \\
\hline & Fitria Husnatarina iD https://orcid.org/0000-0002-6802-9497 \\
\hline ARTICLE INFO & $\begin{array}{l}\text { Helin Garlinia Yudawisastra, Daniel T. H. Manurung and Fitria Husnatarina } \\
\text { (2018). Relationship between value added capital employed, value added } \\
\text { human capital, structural capital value added and financial performance. } \\
\text { Investment Management and Financial Innovations, 15(2), 222-231. } \\
\text { doi:10.21511/imfi.15(2).2018.20 }\end{array}$ \\
\hline DOI & http://dx.doi.org/10.21511/imfi.15(2).2018.20 \\
\hline RELEASED ON & Monday, 11 June 2018 \\
\hline RECEIVED ON & Monday, 26 February 2018 \\
\hline \multirow[t]{2}{*}{ ACCEPTED ON } & Tuesday, 15 May 2018 \\
\hline & $(\mathrm{cc})$ EY-NC \\
\hline LICENSE & $\begin{array}{l}\text { This work is licensed under a Creative Commons Attribution-NonCommercial } 4.0 \\
\text { International License }\end{array}$ \\
\hline JOURNAL & "Investment Management and Financial Innovations" \\
\hline ISSN PRINT & $1810-4967$ \\
\hline ISSN ONLINE & $1812-9358$ \\
\hline PUBLISHER & LLC "Consulting Publishing Company "Business Perspectives" \\
\hline FOUNDER & LLC "Consulting Publishing Company "Business Perspectives" \\
\hline
\end{tabular}

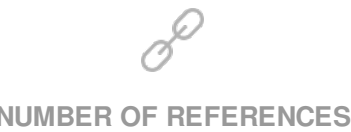

28
NUMBER OF FIGURES

0



NUMBER OF TABLES

7

(C) The author(s) 2022. This publication is an open access article. 


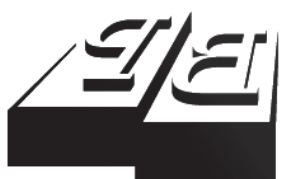

BUSINESS PERSPECTIVES

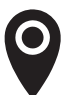

LLC "CPC "Business Perspectives" Hryhorii Skovoroda lane, 10, Sumy, 40022, Ukraine

www.businessperspectives.org

Received on: $26^{\text {th }}$ of February, 2018 Accepted on: $15^{\text {th }}$ of May, 2018

(C) Helin Garlinia Yudawisastra, Daniel T. H. Manurung, Fitria Husnatarina, 2018

Helin Garlinia Yudawisastra, MSi, Lecturer, Faculty of Business and Management, University of Widyatama, Bandung, Indonesia.

Daniel T. H. Manurung, MSA, Lecturer, Faculty of Economics, University of Widyatama, Bandung Indonesia.

Dr. Fitria Husnatarina, MSc., Lecturer of Economics and Business, Palangkaraya University, Palangkaraya, Indonesia.

\section{(ㄷ)(1) $(8$}

This is an Open Access article, distributed under the terms of the Creative Commons Attribution-NonCommercial 4.0 International license, which permits re-use, distribution, and reproduction, provided the materials aren't used for commercial purposes and the original work is properly cited.
Helin Garlinia Yudawisastra (Indonesia), Daniel T. H. Manurung (Indonesia), Fitria Husnatarina (Indonesia)

RELATIONSHIP BETWEEN VALUE ADDED CAPITAL EMPLOYED, VALUE ADDED HUMAN CAPITAL, STRUCTURAL CAPITAL VALUE ADDED AND FINANCIAL PERFORMANCE

\begin{abstract}
Companies that can survive are companies that need to quickly change its strategy from a business based on labor towards knowledge-based business, so that the main characteristics of the company are changed towards a science-based company. This study examines the relationship of value added capital employed, value added human capital, structural capital value added and financial performance. The method of this research is purposive sampling with a total of 34 samples analyzed by using Eviews version 9. The result stated that value added capital employed has no effect on return on asset, value added human capital has an effect on return on asset, structural capital value added has an effect on return on asset.
\end{abstract}

Keywords

JEL Classification value added capital employed, value added human capital, structural capital value added, financial performance, stock index LQ45

E22, G32, O34, O16

\section{INTRODUCTION}

Companies with high intellectual capital are one of the companies listed on the LQ45 index, and have high market capitalization and can demonstrate a consistency of performance. The data obtained from VAIC from 2014 to 2016 amounted to 6,0097, 6,0522 and 6,0840, while ROA data from 2014 to 2016 amounted to $10.186 \%, 8.428 \%$ and $8.433 \%$. The existence of return on asset (ROA) of LQ45 index company is not in line with the state of Intellectual Capital or inversely proportional to phenomenon in the period 2014-2015 and resulted in its performance bung bad enough so that ability of company to yield profit every year has fluctuating condition at the time of company growth, only slightly increased so that it will affect the investor confidence and sustainability of the company by anticipating and knowing the factors that cause the decline in the level of profitability (return on asset) in the next year.

Financial performance is a determinant of specific measures that can measure the success of a company in generating profits and a corporate achievement, which is shown as a display state of the company during a specified period (Devi, Khairunnisa, \& Budiono, 2017). Research was conducted by Sirapanji and Hatane (2015), Habibah and Riharjo (2016), Devi et al. (2017). The research conducted (Chen, Cheng, \& Hwang, 2005; Hussinki, Ritala, Vanhala, \& Kianto, 2017; 
Nik Muhammad \& Ismail, 2009) relates to the financial performance using return on assets as an indicator of company efficiency in utilizing the existing assets and controlling firms' financing policy.

The performance of LQ45 index companies listed on the IDX within the period 2014-2016 shows fairly bad performance, where the ability of companies to generate profits every year has a fluctuating condition, when the company experienced a decline at a very extreme pace, while at the time the company increased, the company only experienced a slight increase. This will have an impact on investor confidence and corporate sustainability. Therefore, it is necessary to anticipate and know the factors of how profitability decreases to minimize the decline in the next year.

The research that has been conducted on Intellectual Capital relates to performance and value creation (Guthrie, Ricceri, \& Dumay, 2012; Inkinen, 2015; Ricceri, 2008). Overall, empirical literature has produced significant evidence of a positive relationship between Intellectual Capital and firm performance. Researchers have also identified a significant correlation between the overall Intellectual Capital level of the firm and its performance outcomes, such as financial performance (Youndt, Subramaniam, \& Snell, 2004), new product development (Y.-S. Chen, James Lin, \& Chang, 2006) and innovation performance (Wu, Chang, \& Chen, 2008). Besides, organizational trust has been found to support collaboration and cooperation (Mayer, Davis, \& Schoorman, 1995) and innovation performance (Ellonen, Blomqvist, \& Puumalainen, 2008). Furthermore, many researchers argue that business-oriented activities affect corporate performance. It deals with self-directed activities within the company, including risk taking, better recognition of new business opportunities, and the willingness and ability to make bold decisions (Hughes \& Morgan, 2007).

Intellectual Capital is a collective knowledge embedded in personnel, organizational routines and organizational networking relationships (Choo \& Bontis, 2002). Intellectual Capital has been recognized as an essential source that organizations need to develop to gain a sustainable competitive advantage (Ming Chen \& Jun Lin, 2004). Intellectual Capital can be defined as the "economic value" of the three categories of intangible assets of the enterprise, which include human capital, organizational capital and social capital collectively. Strategic analysts argue that sustainable development can only occur in situations where human capital differs from organizational capital among firms so that the company can not benefit other companies. Intellectual Capital is recognized as a collection of intangible assets, so it is divided into non-physical assets and acquired by the company's assets. Intellectual Capital is recognized as a collection of intangible assets, thus divided into non-physical assets and acquired by the company's assets (Mojtahedi, 2013).

The more appreciation of a company from these investors is believed to be due to the existence of the company's intellectual capital (Chen et al., 2005; Gozali \& Hatane, 2014), while the understanding of Intellectual Capital is an intangible asset with the ability to give value to the community that includes patents, copyrights, and franchises (Mavridis, 2004; Sirapanji \& Hatane, 2015). The measurement of Intellectual Capital in this study uses value added capital employed, value added human capital and structural capital value added.

Value added capital employed is one component that reflects the book value of the company's net assets (Chen et al., 2005). Research carried out by Gany and Nugrahanti (2015), Habibah and Riharjo (2016) showed that value added capital employed to financial performance has a significant and positive effect, which means companies with efficient operation processes will create favorable conditions for the company and customers. Value added human capital is the contribution generated by each Rupiah invested in capital in the form of human resources to add value to the company (Habibah \& Riharjo, 2016). Tan, Plowman, and Hancock (2007) conducted a study of 150 companies listed on the Singapore Stock Exchange and concluded that the IC has a positive and significant impact on the financial performance of the company, both present and future, while structural capital value added measures the amount of 
Structural Capital (SC) needed to generate 1 Rupiah of value added and is an indication of how structural capital success creates value for the company (Pulic, 1998). Research conducted by Gozali and Hatane (2014) showed that structural capital value added (SCVA) has a positive and most significant impact on company's financial performance and firm value.

Based on previous explanation, this research is aimed at finding out the (1) relationship of value added capital employed with financial performance, (2) value added human capital with financial performance and (3) structural capital value added and financial performance at the company registered in LQ45.

\section{LITERATURE REVIEW}

Some studies only consider the financial aspects of organizational performance, such as equities, assets, or other market-based measures (Reed, Lubatkin, \& Srinivasan, 2006). Other studies only consider non-financial aspects of organizational performance, such as innovation performance (Subramaniam \& Youndt, 2005) or export trends (Youndt et al., 2004). A strategy is a resource allocation pattern that allows a company to maintain or improve performance that creates "fitness" among the company's activities. Simons and Whitbeck (1991) observed that performance measurements tracked the application of business strategy by comparing actual results with strategic objectives and targets. Because performance is the result of activity, performance measurable to analyze performance measurement strategies is probably the most important, but most misunderstood and most challenging task in management accounting (Atkinson at al., 1995; Mojtahedi, 2013).

The company's financial performance is a determinant of certain measures that can measure a company's success in generating profits (Gany \& Nugrahanti, 2015; Devi et al., 2017). Financial performance is measured using return on assets to determine the level of efficiency of the company in utilizing the existing assets and controlling firms financing policy (M.-C. Chen, Cheng, \& Hwang, 2005; Gozali \& Hatane, 2014; Sirapanji \& Hatane, 2015) The level of measurement of return on asset is calculated using the formula:

$$
\text { Return on Asset }=\frac{\text { Net profit after tax }}{\text { Total assets }} \text {. }
$$

Mavridis (2004), Sirapanji and Hatane (2015) say that Intellectual Capital is an intangible asset with the ability to give value to companies and com- munities including patents, intellectual property rights, copyrights, and franchises. The intellectual measurement uses value added capital employed, value added human capital and structural capital value added.

Value added capital employed is an indicator for VA, which is created by a unit of physical capital. This ratio shows the contribution made by each unit of CE to the value added organization (Gozali \& Hatane, 2014; Pulic, 1998). Gany and Nugrahanti (2015), Habibah and Riharjo (2016) state that value added capital employed (VACA) has a positive and significant correlation in forming an Intellectual Capital construct that affects the company's financial performance. The formula for calculating value added capital employed is as follows:

$$
\text { VACA }=\frac{\text { Value Added }}{\text { Capital Employed }}
$$

Value added human capital shows how much value added can be generated with the funds spent on labor. This ratio shows the contribution made by each Rupiah invested in HC to the value added to the organization (Pulic, 1998; Gozali \& Hatane, 2014; Devi et al., 2017). Research that has been done by Habibah and Riharjo (2016) showed that value added human capital has a significant influence on the financial performance of food and beverages companies listed on the Indonesia Stock Exchange, while research conducted by Devi et al. (2017) based on statistical tests showed that the value added human capital (VAHU) has no significant effect on the company's financial performance. The formula for calculating value added capital employed is as follows:

Value added human capital $=\frac{\text { Value added }}{\text { Human capital }}$. 
Structural capital value added, ratio to measure the amount of SC needed to generate 1 Rupiah from VA is an indication of how SC is successful in value creation (Pulic, 1998). Research carried out by Gozali and Hatane (2014), Gany and Nugrahanti (2015), Habibah and Riharjo (2016) showed that structural capital value added (SCVA) has a positive and most significant impact on company's financial performance and firm value.

Structural capital value added $=$

$$
=\frac{\text { Structural capital }}{\text { Value added }} \text {. }
$$

\section{METHOD}

This research uses a quantitative approach with explanatory research type. Explanatory research is a research that explains the causal relationship between variables through testing other hypotheses. This study aims to determine the relationship of the value added capital employed, value added human capital, structural capital value added and financial performance. The population in the study consists of the companies listed in LQ45 from 2014 to 2016 as many as 34 companies. The sample in this research counted 102 sample by using purposive sampling technique. The sampling criteria are as follows: (1) LQ45 index companies listed on the Indonesia Stock Exchange in the period 2014-2016, (2) companies that not survive on the LQ45 index during the study period 20142016 are excluded from the sample, 3) companies that do not suffer losses and balance sheets do not show negative wealth, (4) LQ45 index companies that do not present complete financial statements or disclose information about staff costs (5) comd panies use eye units Rupiah money for their financial statements.

The reason for the selection of samples from LQ45 index companies was because the companies included in the from LQ45 index were able to create value and perform well. In order for a company to be included in the LQ45 index, the company must have shares with certain criteria, that is, to enter the 60 largest rank of total stock transactions in the market, to the enter the ranking based on the market capitalization value, to be listed on the BEI at least for 3 months, corporate financial condi- tion, growth prospects, frequency and number of transactions in the regular market. Companies that are in the LQ45 index are the companies that have a high market capitalization value and can show the consistency of performance. High market capitalization and ability to show the consistency of performance indicates that the company has a high Intellectual Capital compared to other companies. Intellectual Capital is one of the tools for providing more value and corporate excellence. In line with the above matters, it turns out that companies included in the LQ45 index were also selected to be nominations that meet the 8 criteria as finalists of the Indonesian Most Admired Knowledge Enterprise (MAKE) study.

Data analysis technique used in this research is panel data regression by using the program Eviews 9 . Panel data analysis was used to answer hypothesis test about the influence of independent variable on dependent variable. The analysis of data in this study was performed using descriptive analysis, verification analysis and classical assumption test, panel data regression analysis, and hypothesis testing. Panel data regression testing was performed using fixed effect test, classical assumption test, heteroscedasticity test, multicollinearity test, and autocorrelation test.

\section{RESULTS}

\subsection{Panel data regression}

Model selection of panel data regression to estimate the regression model data paradigm in this study is fixed effect to know the result of the independent variable, $t$-statistic, probability, coefficient determination and $f$-test.

Based on Table 3, the regression model in this study is as follows: $Y=-0.033+0.021386 X 1+0$. $004317 X 2+0.129736 X 3$. The interpretation of the regression result is given below.

1. The constant value obtained is -0.033 . This means that if the variable of Value Added Capital Employed (VACA), Value Added Human Capital (VAHU) and Structural Capital Value Added (SCVA) is equal to 0 and there is no change, then, the value of Return On Asset (ROA) is -0.033 . 
Table 1. Panel data regression result

\begin{tabular}{|c|c|c|c|c|}
\hline \multicolumn{5}{|l|}{ Dependent variable: ROA } \\
\hline \multicolumn{5}{|l|}{ Method: Panel least squares } \\
\hline \multicolumn{5}{|l|}{ Date: 10/23/17 Time: 08:32 } \\
\hline \multicolumn{5}{|l|}{ Sample: 2014-2016 } \\
\hline \multicolumn{5}{|l|}{ Periods included: 3} \\
\hline \multicolumn{5}{|l|}{ Cross-sections included: 34} \\
\hline \multicolumn{5}{|c|}{ Total panel (balanced) observation: 102} \\
\hline Variable & Coefficient & Std. Error & $t$-statistic & Prob \\
\hline C & -0.032913 & 0.023589 & -1.395310 & 0.1677 \\
\hline VACA & 0.021386 & 0.026450 & 0.808536 & 0.4217 \\
\hline VAHU & 0.004317 & 0.001163 & 3.710467 & 0.0004 \\
\hline STVA & 0.129736 & 0.035638 & 3.640391 & 0.0005 \\
\hline \multicolumn{5}{|c|}{ Effects specification } \\
\hline \multicolumn{5}{|c|}{ Cross-section fixed (dummy variables) } \\
\hline R-squared & 0.977499 & \multicolumn{2}{|c|}{ Mean dependent var } & 0.090156 \\
\hline Adjusted R-squared & 0.965038 & \multicolumn{2}{|c|}{ S.D. dependent var } & 0.085248 \\
\hline S.E. of regression & 0.015940 & \multicolumn{2}{|c|}{ Akaike info criterion } & -5.165070 \\
\hline Sum squared resid & 0.016515 & \multicolumn{2}{|c|}{ Schwarz criterion } & -4.212874 \\
\hline Log-likelihood & 300.4186 & \multicolumn{2}{|c|}{ Hannan-Quinn criteria } & -4.779493 \\
\hline F-statistic & 78.43922 & \multicolumn{2}{|c|}{ Durbin-Watson stat } & 2.398560 \\
\hline Prob (F-statistic) & 0.000000 & \multicolumn{2}{|c|}{-} & - \\
\hline
\end{tabular}

2. Value of regression coefficient variable Value Added Capital Employed (VACA) is $0.0213>0$. This means if the number of commissioners increases, then, the Return On Asset (ROA) also increased.

3. Value of regression coefficient variable ValueAdded Human Capital (VAHU) is $0.0043>0$. This means that if the independent commissioner increases, then, the Return On Asset (ROA) also increases.

4. The value of regression coefficient of Structural Capital Value Added (SCVA) is 0.1297>0. This means that if Institutional Ownership increases, then, Return On Asset (ROA) also increases.

\subsection{Testing classical assumption}

For testing the classical assumption, normality test, multicollinearity test, heteroscedasticity test, and autocorrelation test will be used.

\subsection{Multicollinearity test}

Multicollinearity test in this research is done by looking at the correlation between independent variables. The provision, if each independent var- iable or independent variable is correlated greater than 0.8 , then, the model includes those having or having a multicollinearity problem or strong enough indication of multicollinearity. The results of multicollinearity test in this study are as follows:

Table 2. Multicollinearity test

\begin{tabular}{|c|c|c|c|}
\hline \multicolumn{4}{|c|}{$\begin{array}{l}\text { Variance inflation factors } \\
\text { Date: } 10 / 23 / 17 \text { Time: 08:32 } \\
\text { Sample: } 1,102 \\
\text { Included observations: } 102\end{array}$} \\
\hline Variable & $\begin{array}{c}\text { Variance } \\
\text { coefficient }\end{array}$ & $\begin{array}{c}\text { Uncentered } \\
\text { VIF }\end{array}$ & Centered VIF \\
\hline C & 0.001313 & 42.10090 & $\mathrm{NA}$ \\
\hline VACA & 0.000982 & 2.689035 & 1.001819 \\
\hline VAHU & $4.47 \mathrm{E}-/ 6$ & 6.158131 & 2.160395 \\
\hline STVA & 0.003315 & 59.53469 & 2.159035 \\
\hline
\end{tabular}

Based on the multicollinearity test, it is seen that all VIF values are less than the critical value set $(\mathrm{VIF}<10)$. Thus, there is no multicollinearity ber tween independent variables. Alternatively, in other words, all the independent variables in the regression model of this study have been mutually independent and tend to be orthogonal.

\subsection{Heteroscedasticity test}

Heteroscedasticity testing was performed in a regression model with the aim to see whether the regression occurred inequality between residual 
variance (errors) from each observation to other observations. Heteroscedasticity testing by incorporating White Heteroskedasticity-Consistent Standard Errors \& Covariance on model testing was performed using Eviews program.

Table 3. Heteroskedasticity test

\begin{tabular}{l:l:l:c}
\hline \multicolumn{4}{c}{ Heteroskedasticity test: White } \\
\hline F-statistic & 1.197748 & Prob. F (3.98) & 0.3147 \\
\hdashline Obs*R-Squared & 3.607631 & Prob. Chi-square (3) & 0.3071 \\
\hdashline $\begin{array}{l}\text { Scaled } \\
\text { explained SS }\end{array}$ & 3.212243 & Prob. Chi-square (3) & 0.36000 \\
\hline
\end{tabular}

Based on heteroscedasticity test, it is seen that Obs ${ }^{\star} \mathrm{R}$-squared is 3.607 with $5 \%$ significance level with probability value 0.307 . Thus, there are no symptoms of heteroscedasticity.

\subsection{Autocorrelation test}

Autocorrelation test aims to test whether in a linear regression model there is a correlation between the confounding error in period $t$ with an error in period $t-1$ (previous). One way to detect the presence or absence of autocorrelation is the DurbinWatson test (DW test).

Table 4. Durbin-Watson autocorrelation test

\begin{tabular}{|c|c|c|c|}
\hline \multicolumn{4}{|c|}{ Autocorrelation Durbin-Watson } \\
\hline R-squared & 0.977499 & $\begin{array}{l}\text { Mean } \\
\text { dependent var }\end{array}$ & 0.090156 \\
\hline $\begin{array}{l}\text { Adjusted } \\
\text { R-squared }\end{array}$ & 0.965038 & $\begin{array}{l}\text { S.D. dependent } \\
\text { var }\end{array}$ & 0.085248 \\
\hline $\begin{array}{l}\text { S.E. of } \\
\text { regression }\end{array}$ & 0.015940 & $\begin{array}{l}\text { Akaike info } \\
\text { criterion }\end{array}$ & -5.165070 \\
\hline $\begin{array}{l}\text { Sum squared } \\
\text { resid }\end{array}$ & 0.016515 & $\begin{array}{l}\text { Schwarz } \\
\text { criterion }\end{array}$ & -4.212874 \\
\hline Log-likelihood & 300.4186 & $\begin{array}{l}\text { Hannan-Quinn } \\
\text { criter. }\end{array}$ & -4.779493 \\
\hline F-statistic & 78.43922 & $\begin{array}{l}\text { Durbin-Watson } \\
\text { stat }\end{array}$ & 2.398560 \\
\hline Prob(F-statistic) & 0.000000 & $=$ & - \\
\hline
\end{tabular}

Based on the Durbin-Watson autocorrelation test, the Durbin-Watson (DW) value generated in this model is 2.238906. As the value of Durbin-Watson generated for 2.398560 lower than the value of 2.46 and greater than 1.54 , it is concluded that there is no autocorrelation in the model.

\subsection{Determination coefficient}

Determination coefficient analysis is conducted to find out the relationship between value added capital employed, value added human capi- tal, structural capital value added and financial performance.

Table 5. Determination coefficient analysis

\begin{tabular}{|c|c|c|c|}
\hline \multicolumn{4}{|c|}{ Determination } \\
\hline R-squared & 0.977499 & $\begin{array}{l}\text { Mean } \\
\text { dependent var }\end{array}$ & 0.090156 \\
\hline $\begin{array}{l}\text { Adjusted } \\
\text { R-squared }\end{array}$ & 0.965038 & $\begin{array}{l}\text { S.D. } \\
\text { dependent var }\end{array}$ & 0.085248 \\
\hline S.E. of regression & 0.015940 & $\begin{array}{l}\text { Akaike info } \\
\text { criterion }\end{array}$ & -5.165070 \\
\hline $\begin{array}{l}\text { Sum squared } \\
\text { resid }\end{array}$ & 0.016515 & $\begin{array}{l}\text { Schwarz } \\
\text { criterion }\end{array}$ & -4.212874 \\
\hline Log-likelihood & 300.4186 & $\begin{array}{l}\text { Hannan- } \\
\text { Quinn criter. }\end{array}$ & -4.779493 \\
\hline F-statistic & 78.43922 & $\begin{array}{l}\text { Durbin- } \\
\text { Watson stat }\end{array}$ & 2.398560 \\
\hline Prob (F-statistic) & 0.000000 & - & - \\
\hline
\end{tabular}

Tests were conducted to determine the relationship between value added capital employed, value added human capital, structural capital value added and financial performance by using the determination coefficient. The test results can be seen in Table 5 of it is known that the value of $R$-squared of 0.9774 means the amount of Value Added Capital Employed (VACA), Value Added Human Capital (VAHU) and Structural Capital Value Added (STVA) contributed $97.74 \%$ to Return On Asset (ROA) and the rest of $2.26 \%$ was affected by other factors.

\subsection{Simultaneous significance test (f-test)}

To determine whether or not there is a significant influence of independent variables on non-free variable, $f$-test is used. Based on Table 6 ( $f$-test), as follows:

Table 6. Hypotheses testing simultaneously ( $f$-test)

\begin{tabular}{|c|c|c|c|}
\hline \multicolumn{4}{|c|}{ Determination coefficient } \\
\hline R-squared & 0.977499 & $\begin{array}{l}\text { Mean } \\
\text { dependent var }\end{array}$ & 0.090156 \\
\hline $\begin{array}{l}\text { Adjusted } \\
\text { R-squared }\end{array}$ & 0.965038 & $\begin{array}{l}\text { S.D. dependent } \\
\text { var }\end{array}$ & 0.085248 \\
\hline S.E. of regression & 0.015940 & $\begin{array}{l}\text { Akaike info } \\
\text { criterion }\end{array}$ & -5.165070 \\
\hline Sum squared resid & 0.016515 & $\begin{array}{l}\text { Schwarz } \\
\text { criterion }\end{array}$ & -4.212874 \\
\hline Log-likelihood & 300.4186 & $\begin{array}{l}\text { Hannan-Quinn } \\
\text { criter. }\end{array}$ & -4.779493 \\
\hline F-statistic & 78.43922 & $\begin{array}{l}\text { Durbin-Watson } \\
\text { stat }\end{array}$ & 2.398560 \\
\hline Prob (F-statistic) & 0.000000 & - & - \\
\hline
\end{tabular}


The probability value ( $F$-statistic) shows that $p$-value is 0.0000 , with the level of $\alpha=5 \%(0.05)$, then, $\mathrm{H} 0$ is rejected. Therefore, it can be concluded that the variables Value Added Capital Employed (VACA), Value Added Human Capital (VAHU) and Structural Capital Value Added (SCVA) together have a significant effect on Return On Asset (ROA).

\subsection{Individual parameter significance test ( $t$-test)}

To know whether or not there is an influence of partially free variables on a dependent variable, $t$-test was used.

Table 7. Partial test of hypotheses ( $t$-test)

\begin{tabular}{l:c:c:c:c}
\hline Variable & Coefficient & Std. Error & t-statistic & Prob \\
\hline C & -0.032913 & 0.023589 & -1.395310 & 0.1677 \\
VACA & 0.021386 & 0.026450 & 0.808536 & 0.4217 \\
\hdashline VAHU & 0.004317 & 0.001163 & 3.710467 & 0.0004 \\
\hdashline SCVA & 0.129736 & 0.035638 & 3.640391 & 0.0005 \\
\hline
\end{tabular}

1. Variable Value Added Capital Employed (X1)

Variable Value Added Capital Employed (VACA) shows that $p$-value equal to 0.4217 with the level $\alpha$ equal to 5\% (0.05), thus $\mathrm{H} 0$ is accepted, it means from this test that there is no influence of Value Added Capital Employed (VACA) variable on Return On Asset (ROA).

2. Variable Value Added Human Capital (X2)

Variable Value Added Human Capital (VAHU) shows that $p$-value is 0.0004 , with the level equal to $5 \%(0.05)$, thus $\mathrm{H} 0$ is rejected. This means that there is partial influence of the variable Value Added Human Capital (VAHU) on Return On Asset (ROA).

\section{Structural Capital Value Added (X3)}

Structural Capital Value Added (SCVA) variable shows $p$-value 0.0005 , with the level $\alpha$ equal to $5 \%$ (0.05), thus $\mathrm{H} 0$ is rejected. It means from this test that there is partial influence of Structural Capital Value Added (SCVA) variable on Return On Asset (ROA).

\section{DISCUSSION}

\subsection{Relationship of Value Added Capital Employed with Return On Asset (ROA)}

Based on the result of regression test of panel data, the research result stated that the value added capital employed does not affect return on asset. No significant effect on Return on Assets (ROA), following the results of panel data regression from $t$-test results of 0.4217 larger than the level of significance of 0.05 . This shows the possibility, because the company has not been able to manage and utilize resources in the form of capital employed well so that the company has not been able to improve its performance using this capital employed. The results are not in line with Gany and Nugrahanti (2015), Habibah and Riharjo (2016), Devi et al. (2017) who stated that value added capital employed has a positive and significant relationship with financial performance. This shows the contribution made by each unit of the physical capital that works against the value added to the organization. This means that knowledge and information possessed by human resources can create value added efficiency to generate company's wealth in the form of physical capital.

\subsection{Relationship of Value Added Human Capital with Return On Asset (ROA)}

Based on the results of research, Value Added Human Capital (VAHU) is related to Return On Asset (ROA). Following the significant results, $t$-test shows the value of 0.0004 , which is smaller than the level of significance of 0.05 . The influence of VAHU on ROA indicates that the amount of contribution made by human capital can improve the company's performance and efficiency and effectiveness of the management of its assets. Companies that can manage their employees will, then, provide added value to the company. The results of this study are in line with the research conducted (Habibah \& Riharjo, 2016), which proves that value added human capital has a significant influence on the financial performance of food and beverages companies listed on the Indonesia Stock 
Exchange. This shows that Value Added Human Capital (VAHU) demonstrates the added value that human resources generate from their ability to apply their skills and expertise. Human capital is a combination of human resource capabilities in an organization to solve business problems.

\subsection{Relationship of Structural Capital Value Added to Return On Assets (ROA)}

Based on the results of research, that Structural Capital Value Added (SCVA) has an effect on Return On Asset (ROA). Following the significant result, of the $t$-test shows the value of 0.0005 , which is smaller than the 0.05 significance level. This states that the magnitude of the contribution made by structural capital can improve the performance of the company in the management of returns to shareholders. Companies that can manage the facilities and infrastructure supporting employee performance well will provide added value to the company. The results are consistent with Gozali and Hatane (2014), Habibah and Riharjo (2016), Devi et al. (2017) who found the influence of structural capital value added of the return on asset. This indicates structural capital or structural capital is the supporting infrastructure, processes, and organizational databases that allow human resources to perform their functions. Structural capital also covers issues such as buildings, hardware, software, processes, patents, and copyrights. Not only that, also but structural capital also includes matters such as organizational image, information systems, and database ownership.

\section{CONCLUSION}

Based on the results of the discussion and analysis that have been done related to the relationship of value added capital employed, value added human capital, structural capital value added and financial performance, it can be concluded:

1. Value Added Capital Employed does not have a significant relationship between one independent variable and dependent variable that is, Value Added Capital Employed with company performance (ROA) of LQ45 index companies in the period 2014-2016, this is known from probability value ( $p$-value) equal to 0.4217 with a significance level $\alpha$ of $5 \%$. The conclusion shows that the high level of contribution to the company's workforce will require more funds to achieve good financial performance.

2. Value Added Human Capital has a significant relationship between one independent variable and the dependent variable that is Value Added Human Capital (VAHU) with company performance (ROA) of LQ45 index companies in the period 2014-2016, this is known from probability value ( $p$-value) of 0.0004 , with a significance level $\alpha$ of $5 \%(0.05)$. The conclusion on value added human capital shows the contribution generated in every Rupiah that has been invested to increase human resources so that it will create new opportunities that can be achieved by the company.

3. Structural Capital Value Added has a significant relationship between one independent variable and the dependent variable, that, is Structural Capital Value Added (SCVA) and company performance (ROA) of LQ45 index companies in the period 2014-2016, this is known from probability value ( $p$-value) of 0.0005 , with a significance level $\alpha$ of $5 \%(0.05)$. Conclusion on structural capital value added shows that capital structure owned by the company could generate financial value for the company. 


\section{REFERENCES}

1. Atkinson, A. B., \& Al., E. (1995). Income Distribution in OECD Countries: Evidence From The Luxembourg Income Study. Soc. Policy Studies No. 18, 164.

2. Chen, M.-C., Cheng, S.-J., \& Hwang, Y. (2005). An Empirical Investigation of the Relationship Between Intellectual Capital And Firms' Market Value And Financial Performance. Journal of Intellectual Capital, 6(2), 159-176. https://doi.org /10.1108/14691930510592771

3. Chen, M., Cheng, S., \& Hwang, Y. (2005). An Empirical Investigation Of The Relationship Between Intellectual Capital And Firms' Market Value And Financial Performance. Journal of Intellectual Capital, 6(2), 159176. Retrieved from https:// www.emeraldinsight.com/doi/ abs/10.1108/14691930510592771

4. Chen, Y.-S., James Lin, M.J., \& Chang, C.-H. (2007). The Influence Of Intellectual Capital On New Product Development Performance The Manufacturing Companies of Taiwan As An Example. Total Quality Management \& Business Excellence, 17(10), 1323-1339. https://doi. org/10.1080/14783360601058979

5. Choo, C. W., \& Bontis, N. (2002). Knowledge, Intellectual Capital, and Strategy. In The Strategic Management of Intellectual Capital and Organizational Knowledge (pp. 3-19).

6. Devi, B. E., Khairunnisa, \& Budiono, E. (2017). Pengaruh Intellectual Capital Terhadap Kinerja Keuangan Perusahaan (Studi Kasus Pada Perusahaan Elektronik, Otomotif dan Komponen yang Terdaftar di Bursa Efek Indonesia Periode 2011-2015). E-Proceeding of Management, 4(1).

7. Ellonen, R., Blomqvist, K., \& Puumalainen, K. (2008). The Role of Trust in Organisational Innovativeness. European Journal of Innovation Management,
11(2), 160-181. https://doi. org/10.1108/14601060810869848

8. Gany, F. P. P., \& Nugrahanti, Y. W. (2015). Pengaruh Intellectual Capital Terhadap Kinerja Perusahaan. In Prosiding Seminar Nasional \& Call For Papers.

9. Gozali, A., \& Hatane, S. E. (2014). Pengaruh Intellectual Capital Terhadap Kinerja Keuangan Dan Nilai Perusahaan Khususnya Di Industri Keuangan Dan Industri Pertambangan Yang Terdaftar Di Bursa Efek Indonesia Tahun 2008-2012. Business Accounting Review, 2(2), 208-217.

10. Guthrie, J., Ricceri, F., \& Dumay, J. (2012). Reflections and projections: A decade of Intellectual Capital Accounting Research. British Accounting Review, 44(2), 68-82.

11. Habibah, B. N., \& Riharjo, I. B. (2016). Pengaruh Intellectual Capital Terhadap Kinerja Keuangan Pada Perusahaan Manufaktur. Jurnal Ilmu Dan Riset Akuntansi, 5(7), 1-16. Retrieved from https://ejournal.stiesia.ac.id/jira/article/ view/2484

12. Hughes, M., \& Morgan, R. E. (2007). Deconstructing the relationship between entrepreneurial orientation and business performance at the embryonic stage of firm growth. Industrial Marketing Management, 36(5), 651-661. http://dx.doi.org/10.1016/j.indmarman.2006.04.003

13. Hussinki, H., Ritala, P., Vanhala, M., \& Kianto, A. (2017). Intellectual capital profiles and financial performance of the firm. The Routledge Companion to Intellectual Capital, (October).

14. Inkinen, H. (2015). Review Of Empirical Research On Intellectual Capital And Firm Performance. Journal of Intellectual Capital, 16(3), 518-
565. Retrieved from https:// www.emeraldinsight.com/doi/ abs/10.1108/JIC-01-2015-0002

15. Mavridis, D. G. (2004). The Intellectual Capital Performance Of The Japanese Banking Sector. Journal of Intellectual Capital, 5(1), 92-115.

16. Mayer, R. C., Davis, J. H., \& Schoorman, F. D. (1995). An Integrative Model Of Organizational Trust. Academy of Management Review, 20(3), 709-734.

17. Ming Chen, H., \& Jun Lin, K. (2004). The Role Of Human Capital Cost In Accounting. Journal of Intellectual Capital, 5(1), 116-130.

18. Mojtahedi, P. (2013). Intellectual Capital Accounting and Its Impact on Organizational Financial Performance : Evidence from Malaysian Firms. Journal of Basic and Applied Scientific Research, 3(3), 840-845.

19. Nik Muhammad, N. M., \& Ismail, M. K. A. (2009). Intellectual capital efficiency and firm's performance: study on malaysian financial sectors. International Journal of Economics and Finance, 1(2), 206-212.

20. Pulic, A. (1998). Measuring The Performance Of Intellectual Potential In The Knowledge Economy. In The $2^{\text {nd }}$ "World Congress on the Management of Intellectual Capital" (pp. 1-20).

21. Reed, K. K., Lubatkin, M., \& Srinivasan, N. (2006). Proposing and testing an intellectual-capital based view of the firm. Journal of Management Studies, 43(4), 867-893.

22. Ricceri, F. (2008). Intellectual capital and knowledge management: strategic management of knowledge resources. In Intellectual capital and knowledge management: Strategic Management of Knowledge Resources (pp. 1-204).

23. Simons, R. L., \& Whitbeck, L. B. (1991). Sexual Abuse as a Precursor to Prostitution and Victimization Among Adolescent and Adult Homeless Women. Journal of Family Issues, 12(3), 361-379. 
24. Sirapanji, O., \& Hatane, S. E. (2015). Pengaruh Intellectual Capital terhadap Kinerja Keuangan dan Nilai Pasar pada Perusahaan Manufaktur yang Terdaftar di Bursa Efek Indonesia Tahun 2008-2013. Business Acc, 3(1), 1-28.

25. Subramaniam, M., \& Youndt, M. A. (2005). The Influence of Intel- lectual Capital on the Types of Innovative Capabilities. Academy of Management Journal.

26. Tan, H., Plowman, D., \& Hancock, P. (2007). Intellectual capital and financial returns of companies. Journal of Intellectual Capital, 8(1), 76-95.

27. Wu, W.-Y., Chang, M.-L., \& Chen, C.-W. (2008). Promoting innovation through the accu- mulation of intellectual capital, social capital, and entrepreneurial orientation. R\&D Management, 38(3), 265-277. https://doi. org/10.1111/1467-9914.00120-i1

28. Youndt, M. A., Subramaniam, M., \& Snell, S. A. (2004). Intellectual Capital Profiles: An Examination of Investments and Returns. Journal of Management Studies, 41(2), 335-361. 